Sādhanā Vol. 38, Part 6, December 2013, pp. 1407-1419. (C) Indian Academy of Sciences

\title{
Experimental study of mechanical properties of friction welded AISI 1021 steels
}

\author{
AMIT HANDA $^{1, *}$ and VIKAS CHAWLA ${ }^{2}$ \\ ${ }^{1}$ Punjab Technical University, Jalandhar 144 004, India \\ ${ }^{2}$ DAV College of Engineering and Technology, Kanina 123 023, India \\ e-mail: handaamit_2002@yahoo.com
}

MS received 5 January 2013; revised 9 March 2013; accepted 3 April 2013

\begin{abstract}
Friction welding is widely used as a mass production method in various industries. In the present study, an experimental set-up was designed in order to achieve friction welding of plastically deformed AISI 1021 steels. In this study, low alloy steel (AISI 1021) was welded under different welding parameters and afterwards the mechanical properties such as tensile strength, impact strength and hardness were experimentally determined. On the basis of the results obtained from the experimentation, the graphs were plotted. It is the strength of welded joints, which is fundamental property to the service reliability of the weldments and hence present work was undertaken to study the influence of axial pressure and rotational speed in friction welded joints. Axial pressure and rotational speed are the two major parameters which can influence the strength and hence the mechanical properties of the friction welded joints. Thus the axial pressure and rotational speed were taken as welding parameters, which reflect the mechanical properties.
\end{abstract}

Keywords. Friction welding; AISI 1021 steel; axial pressure; rotational speed; mechanical properties.

\section{Introduction}

Joining of metals is one of the most essential needs of industries. There are stringent needs of today's fabrication industry demand, the use of cost effective materials and procedures apart from quality and safety standards. Friction welding is one of the versatile and well-established welding processes (Meshram et al 2007) that are capable of giving good quality welds; it gives solid state joining of the materials through the controlled rubbing of the interfaces. Due to thus produced heat softens the material and brought the localized faces into the plasticized form which results in good quality welds (Sathiya et al 2009). In this process heat energy is produced by the interconvertion of mechanical energy into thermal energy at the interfaces of the rubbing components (Sahin et al 2007). In the present study, low alloy steel (AISI 1021) was welded

*For correspondence 
under different welding parameters and afterwards the mechanical properties such as tensile strength, impact strength and hardness were experimentally determined. On the basis of the results obtained from the experimentation, the graphs were plotted.

\section{Experimental procedure}

\subsection{Experimental set-up}

Friction welding set-up has been fabricated for making the sound frictional welded joints, for this the existing lathe machine has been modified to suit the requirements of friction welding machine. The existing lathe machine of 'Kirloskar [MK 1675]' make, speed range 30-1600 rpm, was modified to suit the requirements of this experimentation work. The modifications were done by fitting one more tail stock on the lathe machine. A load cell was designed and fitted between these two tail stocks, to measure the axial pressure applied on the specimens. For making the load cell, the master brake cylinder of TATA make is used, the fluid filled inside the brake cylinder for transmitting the power is of DOT-4. Pressure gauge, range 0-150 MPa, is mounted on the brake cylinder so as to measure axial pressure. The two rods were used with this load cell for transmitting power, namely cylinder pushing rod and load transmitting rod. The handle of the original tail stock was removed to accommodate the load transmitting rod such that the barrel of this tail stock is being guided by the load transmitting rod. At this end of barrel a specimen holder was fitted. This holder securely holds one of the specimens very rigidly. Figure 1 shows the experimental set-up fabricated for the production of friction welds.

\subsection{Material}

AISI 1021 bars were selected for the present study; these low alloy steel bars were selected due to their wide application in the manufacturing industry. For the first set of readings 12 bars of $20 \mathrm{~mm}$ diameter and $100 \mathrm{~mm}$ length were cut from the respective bar. Similarly for next two, another set were prepared. Table 1 shows the actual composition of the material after conducting spectroscopy.

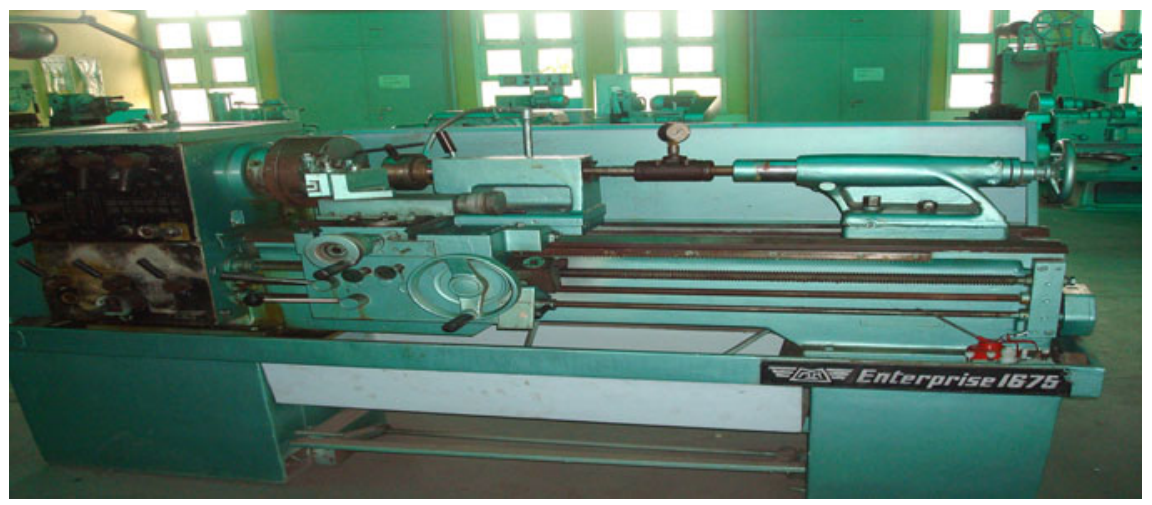

Figure 1. Photograph showing the experimental set-up of friction welding machine. 
Table 1. Chemical composition of AISI 1021.

\begin{tabular}{lcccccr}
\hline Material & $\% \mathrm{C}$ & $\% \mathrm{Mn}$ & $\% \mathrm{~S}$ & $\% \mathrm{P}$ & $\% \mathrm{Si}$ & $\%$ Iron \\
\hline AISI 1021 & 0.22 & 0.65 & 0.03 & 0.03 & 0.23 & Balance
\end{tabular}

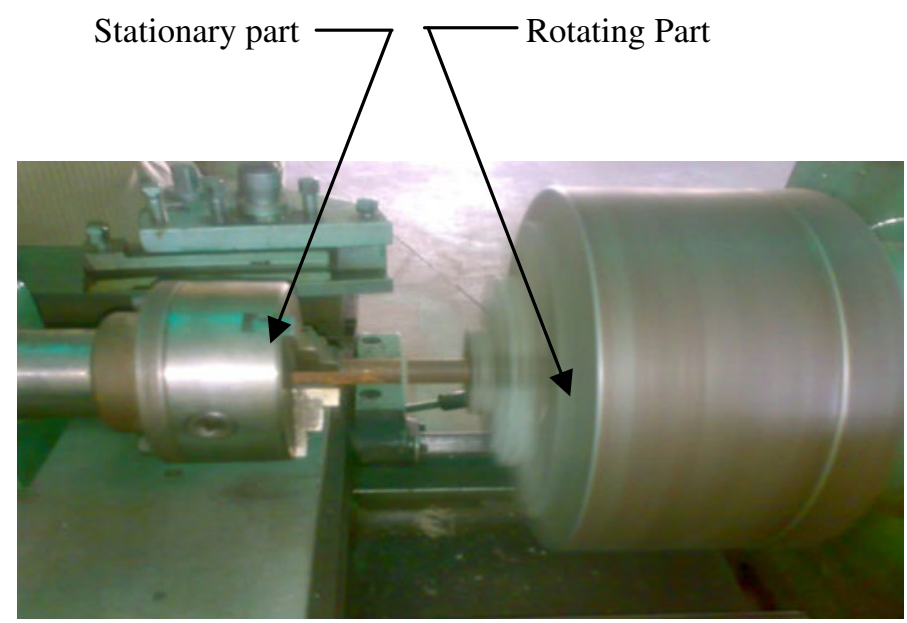

Figure 2. Photograph showing alignment phase of the friction welding process.

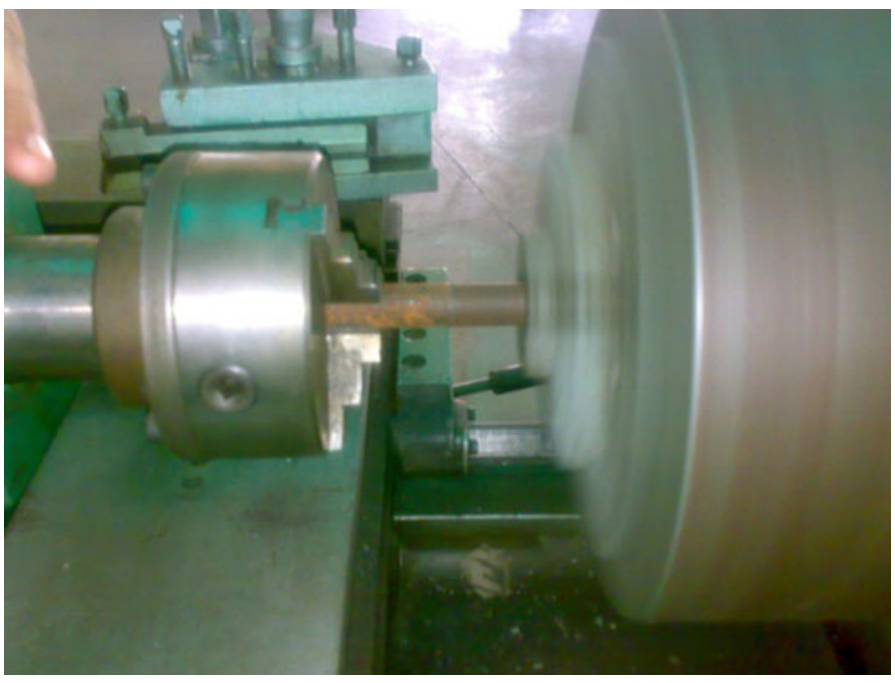

Figure 3. Photograph showing constant phase of the friction welding process. 


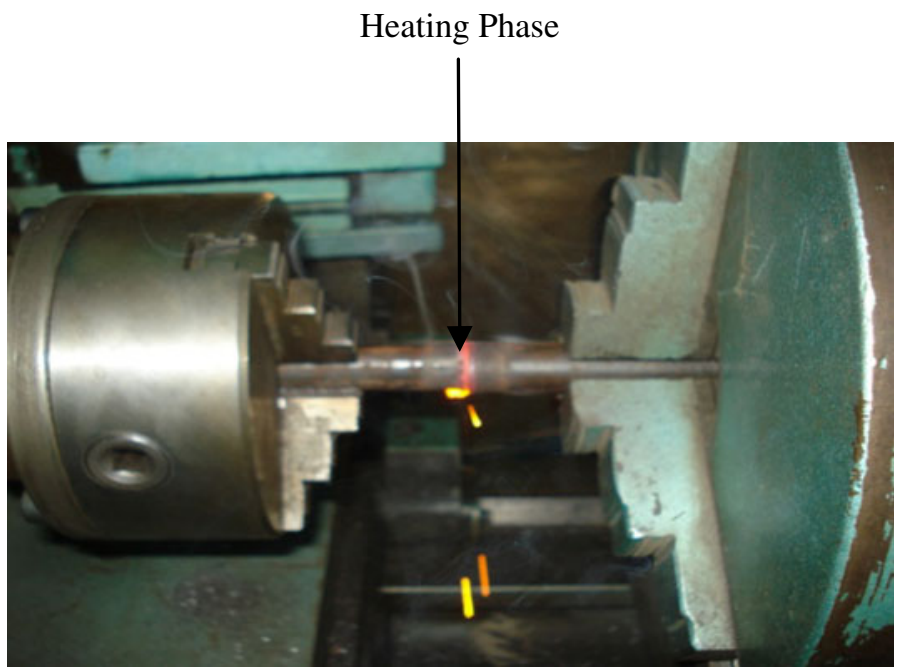

Figure 4. Photograph showing heating phase of the friction welding process.

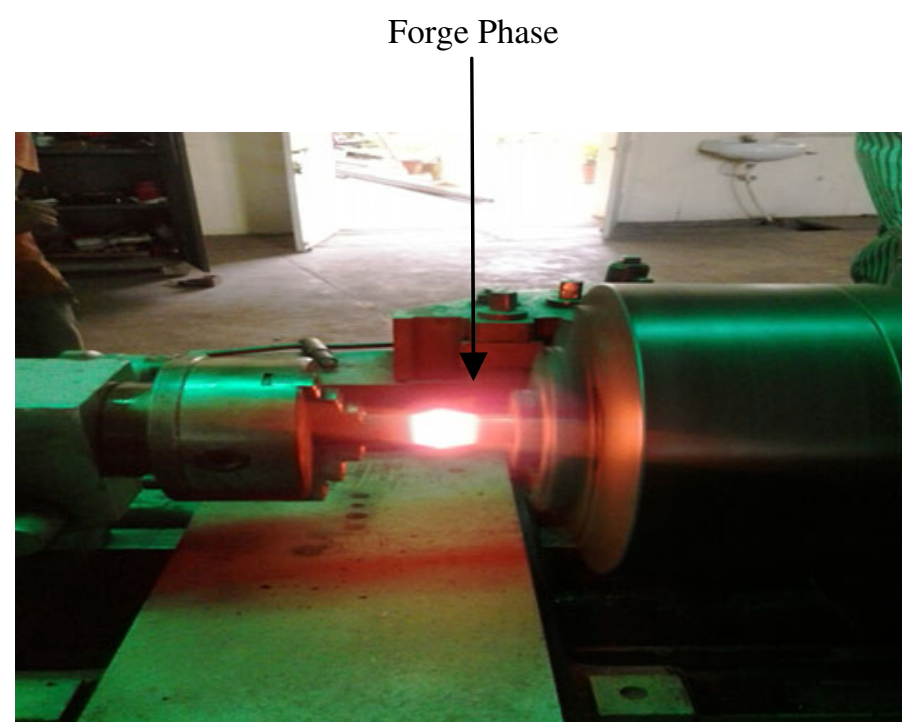

Figure 5. Photograph showing forge phase of the friction welding process.

\subsection{Cleaning and face preparation}

The bars were cleaned mechanically and chemically in order to make them free from oil, dirt, grease, etc. $20 \mathrm{~mm}$ diameter and $100 \mathrm{~mm}$ length of samples were used and the facing operation was done on the lathe machine.

These specimens were then fitted on the friction welding set-up. The experimental set-up used in the present study is of continuous drive type (Sahin 2009). In this method, one component is held stationary while the second component is rotated at constant speed (Sahin 2009). The required rotational speed was set by the levers attached on this machine. Within a fraction of 
seconds, the constant speed was achieved; subsequently the axial alignment of the specimens was checked. Then the heating pressure of $20 \mathrm{MPa}$ was applied which was kept constant for all rotational speeds investigated. When the forging temperature was achieved, the rotation of the head stock was ceased with the help of the lathe brakes. After this, the forging pressure was applied to form the welds. The welds were prepared at different forging pressures in the steps of $15 \mathrm{MPa}$ to form different welds for the study. The welding joint so formed was allowed to cool down for 4-5 minutes. In this way, necessary number of weldments were prepared and subjected to various tests for evaluation of their mechanical properties (figures 2, 3, 4 and 5).

\section{Mechanical testing}

Welded joints were subjected to a variety of mechanical tests to determine their suitability for the anticipated service applications. They were necessary to carry out so as to ensure the quality, reliability and strength of the weldment. There are two methods of testing the quality of the friction welded joint; destructive testing and non-destructive testing. In the former type of testing usually mechanical properties like tensile strength, impact strength and hardness are evaluated. In the present study, the destructive type of testing is employed. In the destructive testing generally the parts were damaged after the test.

\subsection{Tensile test}

Tensile test was performed on the Universal Testing Machine of Blue Star Ltd. make having the capacity $40 \mathrm{~T}$. This test was carried out on the AISI 1021 materials to measure its strength in tension. In this test the specimen was subjected to axial tensile load till its failure occurs.

\subsection{Charpy impact test}

A pendulum type single blow impact test, in this the specimen was supported at both ends as a simple supported beam and was broken by a falling pendulum on the face opposite to the notch and the energy absorbed was noted.

\subsection{Rockwell hardness test}

In this test a diamond indenter was used under a load of $150 \mathrm{~kg}$ to make indent on the prepared samples. The reading was directly taken from $\mathrm{C}$ scale on of the meter of hardness testing machine.

\section{Results}

\subsection{Tensile test}

The tensile strength vs axial pressure plots at $800 \mathrm{rpm}$ are shown in figure 6 . It indicates, that as we go on increasing the axial pressure the tensile strength is also go on increasing, the maximum tensile strength in this plot is achieved at $135 \mathrm{MPa}$ axial pressures, it has also been observed that there is marginal increase in the tensile strength when the axial pressure increased from $120 \mathrm{MPa}$ to $135 \mathrm{MPa}$. Figure 7 also depicts that the tensile strength go on increasing with the increase in axial pressure, but when the axial pressure $120 \mathrm{MPa}$ there is a bit of decline in tensile strength. Welds prepared at $1250 \mathrm{rpm}$ were plotted in figure 8 reveals the similar trends as has 


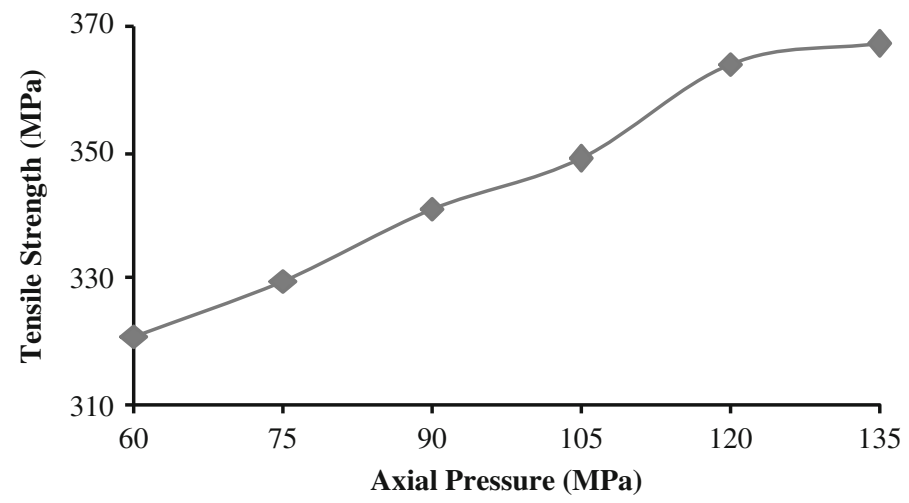

Figure 6. Showing the variation of tensile strength with axial pressure for 1021 specimens joined by the friction welding at $800 \mathrm{rpm}$.

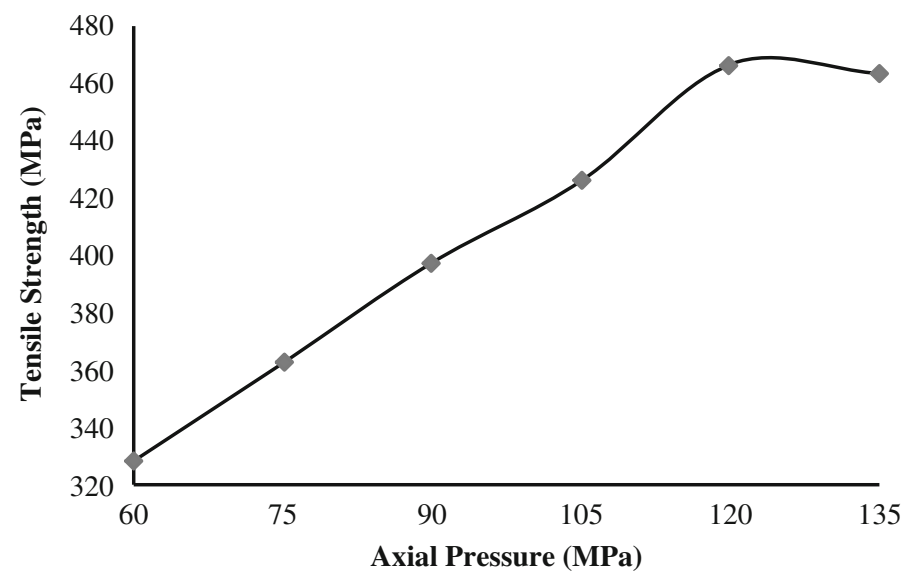

Figure 7. Showing the variation of tensile strength with axial pressure for 1021 specimens joined by the friction welding at $1000 \mathrm{rpm}$.

been observed in figure 7. Means that the strength increases with the increase in axial pressure up to $120 \mathrm{MPa}$ and then there is a little decrease in strength. The maximum tensile strength of $472 \mathrm{MPa}$ was achieved at the axial pressure of $120 \mathrm{MPa}$ at the rotational speed of $1250 \mathrm{rpm}$. Similar results have been reported in the literature (Ates et al 2007).

The visual inspection of the fractured parts revealed that most of the specimens were failed at the weld interfaces and brittle fracture appears to be occurred. But the samples prepared at the axial pressures of $120 \mathrm{MPa}$ and $135 \mathrm{MPa}$ at the rotational speeds of $1000 \mathrm{rpm}$ and $1250 \mathrm{rpm}$ show the sign of necking before failure occurs. Some authors also reported similar trends (Satyanarayana et al 2005). These four specimens also took more time before failure occurs. The maximum time taken by the sample was $21 \mathrm{~s}$ before failure occurs and was prepared at $1250 \mathrm{rpm}$ at $120 \mathrm{MPa}$ axial pressures (tables 2, 3, 4, 5, 6, 7, 8, 9 and 10). 


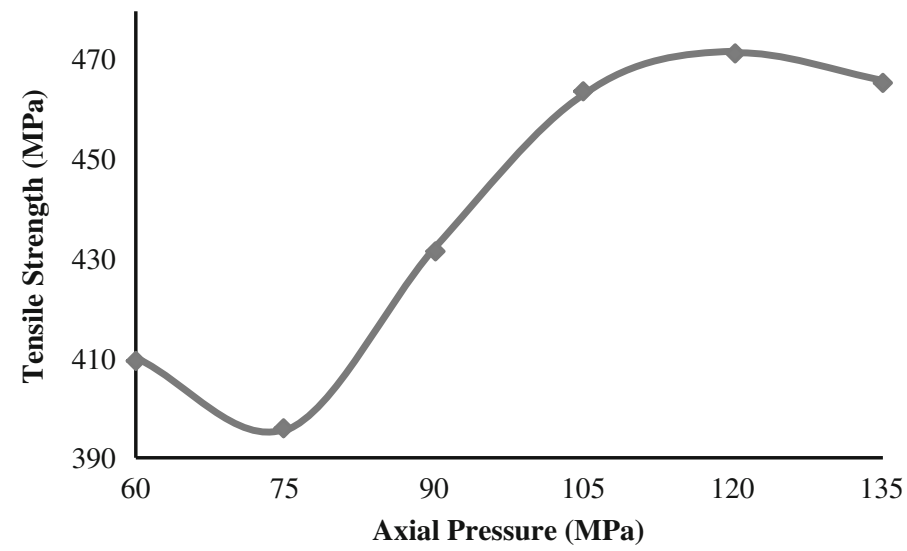

Figure 8. Showing the variation of tensile strength with axial pressure for 1021 specimens joined by the friction welding at $1250 \mathrm{rpm}$.

Table 2. For the specimens joined by the friction welding at $800 \mathrm{rpm}$.

\begin{tabular}{lccc}
\hline S1. No. & Specimen & Axial pressure $(\mathrm{MPa})$ & Tensile strength (MPa) \\
\hline 1 & 1A-1B & 60 & 321 \\
2 & 2A-2B & 75 & 330 \\
3 & 3A-3B & 90 & 341 \\
4 & 4A-4B & 105 & 349 \\
5 & $5 \mathrm{~A}-5 \mathrm{~B}$ & 120 & 364 \\
6 & 6A-6B & 135 & 367 \\
\hline
\end{tabular}

Table 3. For the friction welded specimen at $1000 \mathrm{rpm}$.

\begin{tabular}{lccc}
\hline S1. No. & Specimen & Axial pressure $(\mathrm{MPa})$ & Tensile strength $(\mathrm{MPa})$ \\
\hline 1 & 1A-1B & 60 & 328 \\
2 & 2A-2B & 75 & 363 \\
3 & 3A-3B & 90 & 398 \\
4 & $4 \mathrm{~A}-4 \mathrm{~B}$ & 105 & 426 \\
5 & 5A-5B & 120 & 467 \\
6 & 6A-6B & 135 & 464 \\
\hline
\end{tabular}

Table 4. For the specimens joined by the friction welding at $1250 \mathrm{rpm}$.

\begin{tabular}{lccc}
\hline Sl. No. & Specimen & Axial pressure (MPa) & Tensile strength (MPa) \\
\hline 1 & 1A-1B & 60 & 410 \\
2 & 2A-2B & 75 & 396 \\
3 & 3A-3B & 90 & 432 \\
4 & $4 \mathrm{~A}-4 \mathrm{~B}$ & 105 & 464 \\
5 & 5A-5B & 120 & 472 \\
6 & 6A-6B & 135 & 466 \\
\hline
\end{tabular}


Table 5. Shows the variation of Charpy impact strength with axial pressure for 1021 specimen welded at $800 \mathrm{rpm}$.

\begin{tabular}{lccc}
\hline Sl. No. & Specimen & Axial pressure $(\mathrm{MPa})$ & Energy absorbed $(\mathrm{J})$ \\
\hline 1 & 1A-1B & 60 & 27 \\
2 & 2A-2B & 75 & 26 \\
3 & $3 \mathrm{~A}-3 \mathrm{~B}$ & 90 & 22 \\
4 & $4 \mathrm{~A}-4 \mathrm{~B}$ & 105 & 19 \\
5 & $5 \mathrm{~A}-5 \mathrm{~B}$ & 120 & 20 \\
6 & 6A-6B & 135 & 17 \\
\hline
\end{tabular}

Table 6. Shows the variation of Charpy impact strength with axial pressure for 1021 specimen welded at $1000 \mathrm{rpm}$.

\begin{tabular}{lccc}
\hline Sl. No. & Specimen & Axial pressure $(\mathrm{MPa})$ & Energy absorbed (J) \\
\hline 1 & 1A-1B & 60 & 28 \\
2 & 2A-2B & 75 & 25 \\
3 & 3A-3B & 90 & 27 \\
4 & $4 \mathrm{~A}-4 \mathrm{~B}$ & 105 & 24 \\
5 & 5A-5B & 120 & 23 \\
6 & 6A-6B & 135 & 23 \\
\hline
\end{tabular}

Table 7. Shows the variation of Charpy impact strength with axial pressure for 1021 specimen welded at $1250 \mathrm{rpm}$.

\begin{tabular}{lccc}
\hline Sl. No. & Specimen & Axial pressure (MPa) & Energy absorbed (J) \\
\hline 1 & 1A-1B & 60 & 29 \\
2 & 2A-2B & 75 & 27 \\
3 & 3A-3B & 90 & 26 \\
4 & 4A-4B & 105 & 26 \\
5 & 5A-5B & 120 & 24 \\
6 & 6A-6B & 135 & 23 \\
\hline
\end{tabular}

Table 8. Showing the variation of Rockwell hardness on $\mathrm{C}$ scale at a distance away from the center of the welded surface at $800 \mathrm{rpm}$.

\begin{tabular}{|c|c|c|c|c|c|c|}
\hline \multirow[b]{2}{*}{ Specimen } & \multirow{2}{*}{$\begin{array}{c}\text { Axial } \\
\text { pressure } \\
(\mathrm{MPa})\end{array}$} & \multicolumn{4}{|c|}{$\begin{array}{c}\text { Rockwell hardness on C scale at a distance } \\
\text { from weld interface }(\mathrm{mm})\end{array}$} & \multirow[b]{2}{*}{8} \\
\hline & & 0 & 2 & 4 & 6 & \\
\hline $\mathrm{A}$ & 60 & 10 & 12 & 9 & 9 & 8 \\
\hline B & 75 & 13 & 15 & 13 & 11 & 9 \\
\hline $\mathrm{C}$ & 90 & 12 & 12 & 10 & 8 & 7 \\
\hline $\mathrm{D}$ & 105 & 12 & 11 & 11 & 9 & 9 \\
\hline $\mathrm{E}$ & 120 & 14 & 16 & 10 & 13 & 10 \\
\hline $\mathrm{F}$ & 135 & 15 & 14 & 12 & 12 & 8 \\
\hline
\end{tabular}


Table 9. Showing the variation of Rockwell hardness on $\mathrm{C}$ scale at a distance away from the center of the welded surface at 1000 0rpm.

\begin{tabular}{|c|c|c|c|c|c|c|}
\hline \multirow[b]{2}{*}{ Specimen } & \multirow{2}{*}{$\begin{array}{c}\text { Axial } \\
\text { pressure } \\
(\mathrm{MPa})\end{array}$} & \multicolumn{5}{|c|}{$\begin{array}{c}\text { Rockwell hardness on } \mathrm{C} \text { scale at a distance } \\
\text { from weld interface }(\mathrm{mm})\end{array}$} \\
\hline & & 0 & 2 & 4 & 6 & 8 \\
\hline A & 60 & 12 & 11 & 10 & 11 & 7 \\
\hline B & 75 & 14 & 11 & 12 & 9 & 6 \\
\hline $\mathrm{C}$ & 90 & 10 & 14 & 11 & 9 & 7 \\
\hline D & 105 & 12 & 13 & 12 & 11 & 9 \\
\hline $\mathrm{E}$ & 120 & 11 & 14 & 11 & 13 & 8 \\
\hline $\mathrm{F}$ & 135 & 14 & 15 & 12 & 10 & 10 \\
\hline
\end{tabular}

Table 10. Showing the variation of Rockwell hardness on $\mathrm{C}$ scale at a distance away from the center of the welded surface at $1250 \mathrm{rpm}$.

\begin{tabular}{|c|c|c|c|c|c|c|}
\hline \multirow[b]{2}{*}{ Specimen } & \multirow{2}{*}{$\begin{array}{c}\text { Axial } \\
\text { pressure } \\
(\mathrm{MPa})\end{array}$} & \multicolumn{4}{|c|}{$\begin{array}{c}\text { Rockwell hardness on } \mathrm{C} \text { scale at a distance } \\
\text { from weld interface }(\mathrm{mm})\end{array}$} & \multirow[b]{2}{*}{8} \\
\hline & & 0 & 2 & 4 & 6 & \\
\hline A & 60 & 12 & 11 & 11 & 10 & 8 \\
\hline B & 75 & 14 & 12 & 11 & 10 & 8 \\
\hline $\mathrm{C}$ & 90 & 14 & 14 & 10 & 9 & 10 \\
\hline D & 105 & 9 & 10 & 11 & 9 & 7 \\
\hline $\mathrm{E}$ & 120 & 11 & 14 & 13 & 12 & 7 \\
\hline $\mathrm{F}$ & 135 & 16 & 18 & 16 & 13 & 11 \\
\hline
\end{tabular}

\subsection{Impact test}

Corresponding graphs of friction welds prepared at $800 \mathrm{rpm}, 1000 \mathrm{rpm}$ and $1250 \mathrm{rpm}$ with different axial pressures have been plotted on the bases of results shown by the specimens. Figure 9 shows the relationship between the energy absorbed by the specimens and the axial pressures at 800 rotational speeds. It depicts the variation of Charpy impact strength with the variation in the axial pressures, and shows that for every specimen the energy absorbed decreases with the increase in the axial pressures. Figure 10 plotted at 1000 rotational speeds also shows the similar trend instead at $90 \mathrm{MPa}$ where the impact strength suddenly increases and then with the increase in axial pressure instead of increasing, it decreases little, but remains constant with the further increase in axial pressure. The graph plotted at $1250 \mathrm{rpm}$ shows the trend that the impact strength decreases up to $90 \mathrm{MPa}$ axial pressure, then it remains constant at $105 \mathrm{MPa}$, and then again starts decreasing.

From the above results, it has been found that with the increase in axial pressure the impact strength decreases, but the impact strength increases with the increase in rotational speeds in general. It is also evident that maximum Charpy impact strength was found to be 29 Joules which was obtained at $1250 \mathrm{rpm}$. The least impact strength was found at $135 \mathrm{MPa}$ axial pressures at $800 \mathrm{rpm}$, it has also been found that minimum impact strength was observed at $135 \mathrm{MPa}$ at all the three different rotational speeds and there is a steep rise in the strength with the increase in the rotational speeds. It has also been observed that with the increase in the axial pressure the flash increases, and experimentally it has been found that with the increase in the flash the 


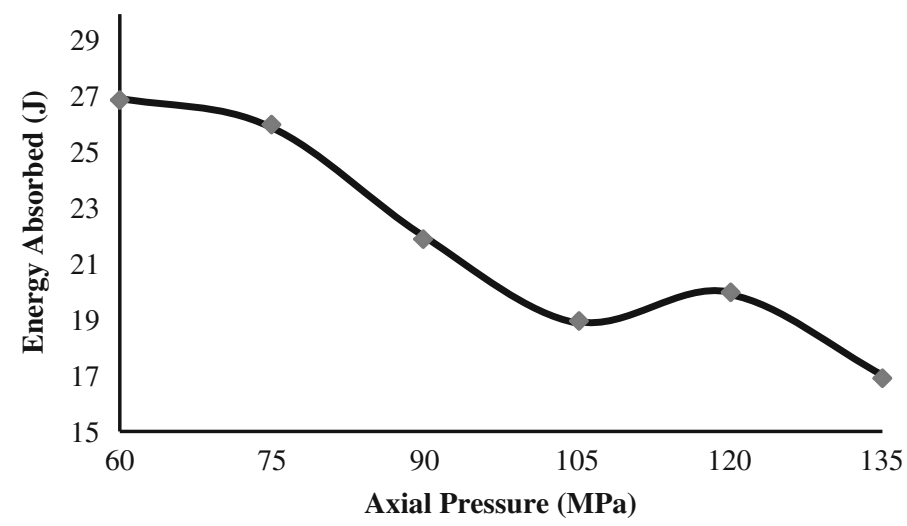

Figure 9. Showing the variation of Charpy impact strength with axial pressure for 1021 specimens welded at $800 \mathrm{rpm}$.

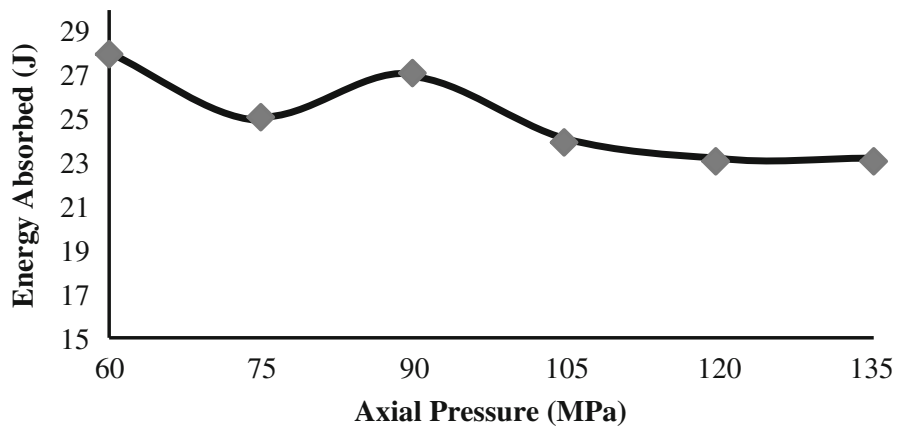

Figure 10. Showing the variation of Charpy impact strength with axial pressure for 1021 specimens welded at $1000 \mathrm{rpm}$.

impact strength decreases. Similar results have been quoted by different authors (Arivazhagan et al 2008, 2011) and our results are quite comparable with the literature (figure 11).

\subsection{Hardness test}

Figure 12 shows the variation of Rockwell hardness on C scale (HRC) at the weld interface and away from the centre of weld interface of specimens, friction welds prepared at $800 \mathrm{rpm}$ with several axial pressures. It is evident from the curves that there is comparatively large variation in the hardness for the welds prepared at $135 \mathrm{MPa}$ axial pressures. Whereas the variation in hardness is less for the other cases, which contributes a favourable condition for better quality welds. Figure 13 depicts large variation in the hardness curves plotted for axial pressure of $135 \mathrm{MPa}$, and therefore indicates that the welds formed are not economical. Corresponding plots at $1250 \mathrm{rpm}$ shown in figure 14 depict that the hardness value reaches up to $18 \mathrm{HRC}$. Maximum hardness was found at the weld interfaces for almost every case, this might be attributed to the maximum temperature which was generated at the rubbing faces. As we go away from the weld interface, the HRC go on decreasing showing the low heat affected zone. From the above discussion it has been clear that, in all the cases, when the axial pressure is increased beyond $120 \mathrm{MPa}$ there is an increase in the hardness at the weld interfaces, which is not a favourable 


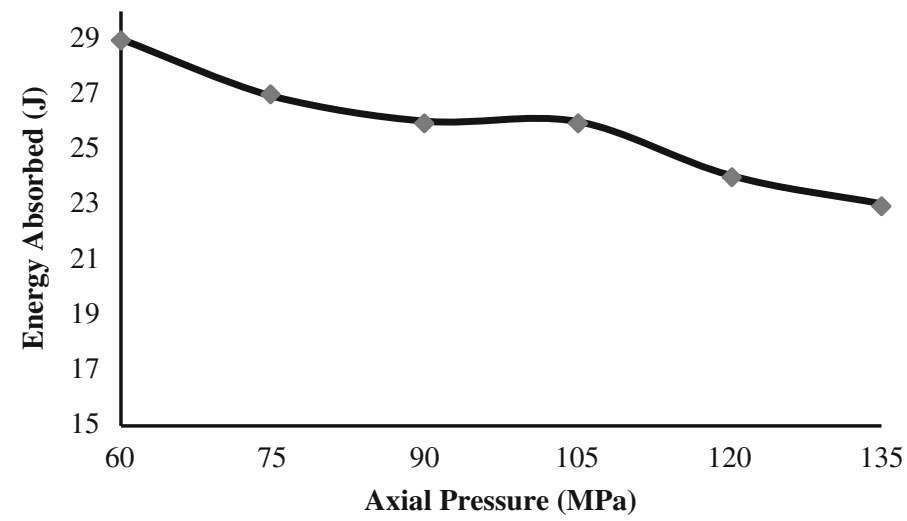

Figure 11. Showing the variation of Charpy impact strength with axial pressure for 1021 specimens welded at $1250 \mathrm{rpm}$.
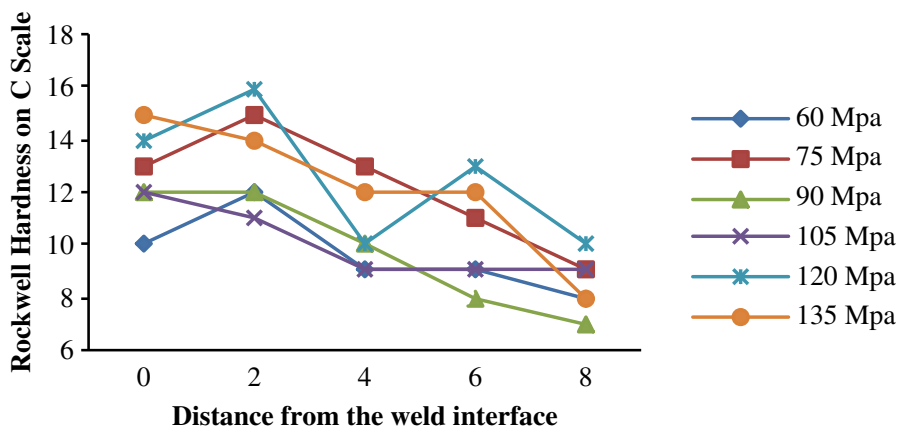

Figure 12. Rockwell hardness on $\mathrm{C}$ scale distance center of welded surface at $800 \mathrm{rpm}$.
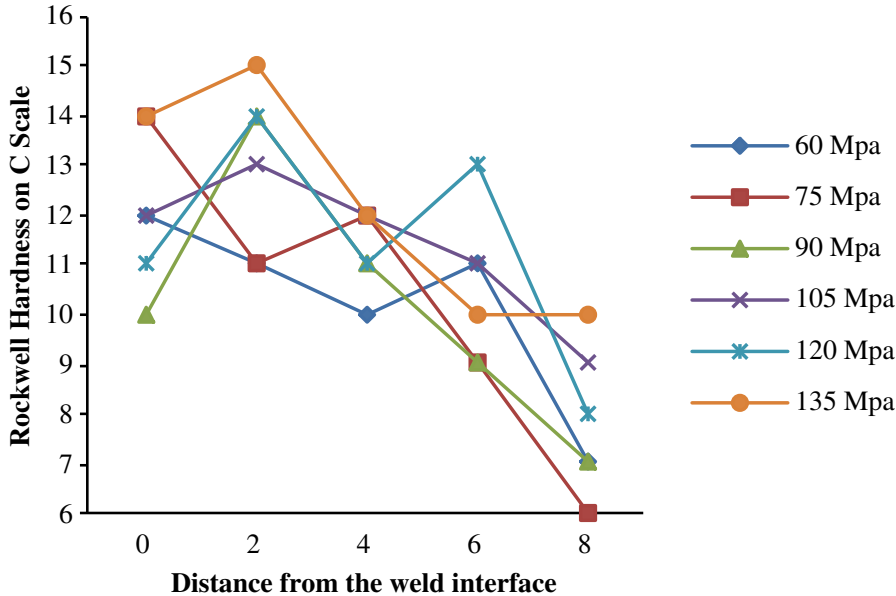

Figure 13. Showing variation of Rockwell hardness on $\mathrm{C}$ scale at a distance away from the center of welded surface at $1000 \mathrm{rpm}$. 


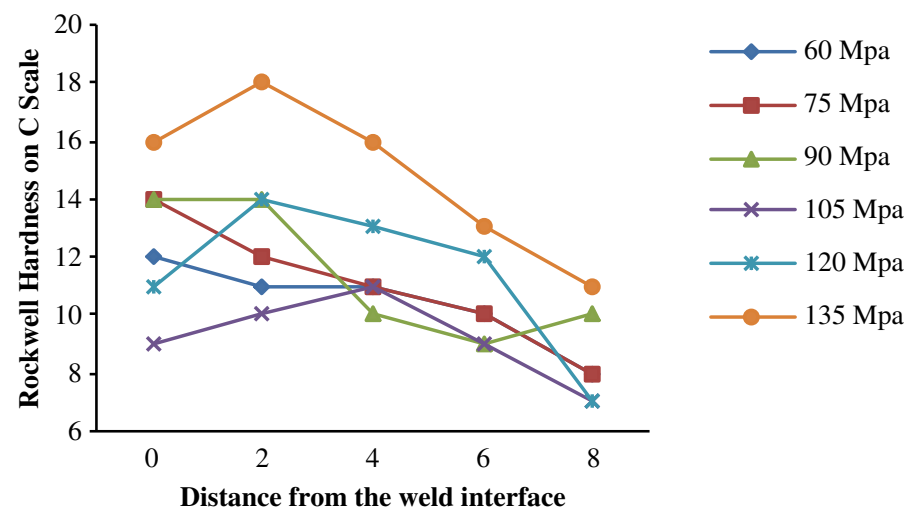

Figure 14. Showing the variation of Rockwell hardness on $\mathrm{C}$ scale at a distance away from the center of the welded surface at $1250 \mathrm{rpm}$.

condition for efficient welds. Whereas at the remaining pressures of $60 \mathrm{MPa}, 75 \mathrm{MPa}, 90 \mathrm{MPa}$, $105 \mathrm{MPa}$ and $120 \mathrm{MPa}$, it has been observed that although there is relatively a little bit variation in the hardness, however during mechanical testing i.e., tensile and impact testing it has shown that the results produced with the axial pressure of $60 \mathrm{MPa}, 75 \mathrm{MPa}$, and $90 \mathrm{MPa}$ were not optimum and hence these pressure do not meet the requirements of an efficient weldment. The tensile and impact properties obtained at $120 \mathrm{MPa}$ axial pressure at $1250 \mathrm{rpm}$ were found to be maximum in addition to relatively small hardness variations. In this way it can be concluded that an axial pressure of $120 \mathrm{MPa}$ may be used to produce efficient and economical welds at 1250 rotational speeds.

\section{Discussion}

A friction welding set-up was designed and fabricated (Sahin 2009). Subsequently, friction welds were prepared from the AISI 1021 steel bars. The welds were prepared at the rotational speeds of 800, 1000 and $1250 \mathrm{rpm}$, with several axial pressures ranging from $60 \mathrm{MPa}$ to $135 \mathrm{MPa}$. The axial pressures were applied in the incremental steps of $15 \mathrm{MPa}$ at each chosen rotational speeds. The welded specimens were then subjected to tensile test, impact test and hardness test to evaluate their mechanical properties and establish the quality of the welds. The tensile strength of the welded specimens was evaluated from tensile testing on universal testing machine. It was found that a maximum tensile strength could be achieved at the rotational speed of $1250 \mathrm{rpm}$ with an axial pressure of $120 \mathrm{MPa}$. This means that an axial pressure of $120 \mathrm{MPa}$ and a rotational speed of $1250 \mathrm{rpm}$ can be used to obtain a weld with best tensile strength.

The Charpy impact tests were performed on the welded specimens. The energy absorbed by the specimens before fracture has been measured. It was observed that a maximum Charpy impact strength was also found at the same rotational speed i.e., $1250 \mathrm{rpm}$, also good impact toughness was achieved at $120 \mathrm{MPa}$ axial pressures.

From the above discussion, it has been concluded that a maximum tensile strength, as well as, impact could be obtained at a rotational speed of $1250 \mathrm{rpm}$ with an axial pressure of $120 \mathrm{MPa}$. Rockwell hardness was also measured for all the welded specimens so as to ascertain variation of hardness with distance from the centre of the weld interface. Hardness values were measured at the centre of weld interface across the cross sectional area and away from the centre at various 
points. It was observed that variation of hardness was found to be acceptable for the weldments produced at $1250 \mathrm{rpm}$ and $120 \mathrm{MPa}$. This means that the hardness of the weldbead was almost same at these parameters.

\section{Conclusions}

The following conclusions are made from the study:

(i) The laboratory built friction welding set-up was found to be successful for the production of friction welds.

(ii) The rotational speed of the job has been found to be an influential parameter for the friction welding process, which has been optimized for the process based on the results of the present study.

(iii) The mechanical properties of the friction welds were found to vary with the applied axial pressure, which indicates that axial pressure is an important welding parameter. The axial pressure could be successfully optimized for the friction welding process on the basis of the results of the current investigation.

(iv) The maximum tensile strength for welded bars was achieved at a rotational speed of $1250 \mathrm{rpm}$ with an applied axial pressure of $120 \mathrm{MPa}$.

(v) It has also been observed that the impact strength for the weldments was also acceptable at $1250 \mathrm{rpm}$ and $120 \mathrm{MPa}$ axial pressure.

(vi) With the increase in the axial pressure, the hardness at the centre of weld cross section increases.

(vii) The value of hardness also increases with increase in the rotational speed.

\section{References}

Arivazhagan N, Singh S, Prakash S and Reddy GM 2008 An assessment of hardness, impact strength and hot corrosion behavior of friction-welded dissimilar weldments between AISI 4140 and AISI 304. Int. J. Adv. Manuf. Technol. 39: 679-689

Arivazhagan N, Singh S, Prakash S and Reddy GM 2011 Investigation of AISI 304 austenitic stainless steel to AISI 4140 low alloy steel dissimilar joints by gas tungsten arc, electron beam and friction welding. Materials and Design 32: 3036-3050

Ates H, Turker M and Kurt A 2007 Effect of friction pressure on the properties of friction welded MA956 iron-based superalloy. Materials and Design 28: 948-953

Meshram SD, Mohandas T and Reddy GM 2007 Friction welding of dissimilar pure metals. Journal of Materials Processing Technology 184: 330-337

Sahin M 2009 Characterization of properties in plastically deformed austenitic-stainless steels joined by friction welding. Materials and Design 30: 135-144

Sahin M, Akata HE and Gulmez T 2007 Characterization of mechanical properties in AISI 1040 parts welded by friction welding. Materials Characterization 58: 1033-1038

Sathiya P, Aravindan S, Haq AN and Paneerselvam K 2009 Optimization of friction welding parameter using evolutionary computational techniques. Journal of Materials Processing Technology 209: $2576-2584$

Satyanarayana VV, Reddy GM and Mohandas T 2005 Dissimilar metal friction welding of austeniticferritic stainless steels. Journal of Materials Processing Technology 160: 128-137 